\title{
Kontribusi Industri Rumahan dalam Meningkatkan Pertumbuhan Ekonomi di Kota Watampone
}

\author{
Akmal Ihsan \\ Institut Agama Islam Negeri (IAIN) Bone \\ akmaliainbone@yahoo.co.id \\ Firdaus \\ Sekolah Tinggi Agama Islam (STAI) Al -Furqan Makassar \\ firdausstaialfurqan@gmail.com
}

\begin{abstract}
This study discusses the contribution of home industries in increasing economic growth in Watampone City. The formulation of the problem in this study is: Is the home industry contributing significantly in increasing economic growth in Watampone City. The purpose of this study is to find out whether the home industry contributes significantly in increasing economic growth in Watampone City. The results showed that, in part, the home industry contributed significantly to economic growth in Watampone City because $t$ count> $t$ table $(2.563>0.013)$ where the significance <significance level $(0,000<0.05)$, as well as\% home industry revenue and\% economic growth in the same direction (=) so that it gives a positive contribution and this shows that $\mathrm{HO}$ is rejected and $\mathrm{H} 1$ is accepted.
\end{abstract}

Keywords: Contributions, Home Industry, Economic Growth

\begin{abstract}
Abstrak
Penelitian ini membahas tentang kontribusi industri rumahan dalam meningkatkan pertumbuhan ekonomi di Kota Watampone. Rumusan masalah dalam penelitian ini adalah: Apakah industri rumahan berkontribusi signifikan dalam meningkatkan pertumbuhan ekonomi di Kota Watampone. Adapun tujuan dari penelitian ini adalah untuk mengetahui apakah industri rumahan berkontribusi signifikan dalam meningkatkan pertumbuhan ekonomi di Kota Watampone. Hasil penelitian menunjukkan bahwa, secara parsial industri rumahan berkontribusi signifikan tehadap pertumbuhan ekonomi di Kota Watampone karena $t$ hitung $>t$ tabel $(2,563>0,013)$ di mana signifikansi < taraf signifikansi $(0,000<0,05)$, begitupun dengan \%pendapatan industri rumahan dan \%pertumbuhan ekonomi searah (=) sehingga memberikan kontribusi yang positif dan ini mnunjukkan bahwa HO ditolak dan $\mathrm{H} 1$ diterima.
\end{abstract}

Kata Kunci : Kontribusi, Industri Rumahan, Pertumbuhan Ekonomi

Jurnal Ilmiah Al Tsarwah

Program Magister Program Studi Ekonomi Syariah

Institut Agama Islam Negeri (IAIN) Bone 


\section{PENDAHULUAN}

Pembangunan ekonomi adalah hal yang sangat penting dalam suatu daerah ataupun suatu Negara, terutama dalam meningkatkan pendapatan dan meningkatkan kesejahteraan rakyatnya. Salah satu sektor pendukung dalam pembangunan ekonomi suatu daerah yaitu industri rumahan (home industry) dan usaha kecil menengah (UKM).

"Menurut Andi Irawan, industri rumahan adalah kegiatan ekonomi yang dilakukan oleh perseorangan atau rumah tangga maupun suatu badan, bertujuan untuk memproduksi barang ataupun jasa untuk diperniagakan secara komersial, yang mempunyai kekayaan bersih paling banyak Rp. 200 juta, dan mempunyai nilai penjualan per tahun sebesar Rp. 1 milyar atau kurang."

Sedangkan UKM menurut Badan Pusat Statistik (BPS) menyusun kategori berdasarkan jumlah tenaga kerja. Menurut BPS, UKM adalah entitas bisnis yang memiliki tenaga kerja yang kurang dari 100 orang, dengan rincian kategori sebagai berikut: usaha rumah tangga dan mikro terdiri dari satu sampai dengan empat tenaga kerja, usaha kecil terdiri dari lima sampai dengan 19 orang, usaha menengah terdiri dari 20 sampai dengan 99 orang. $^{2}$

Secara umum peningkatan industri rumahan (home industry) dan UKM diyakini memiliki kontribusi terhadap pembangunan ekonomi suatu daerah. Melihat pertumbuhan ekonomi, khususnya di kota Watampone saat ini terbilang cukup pesat, laju pertumbuhan produk domestik regional bruto dari tahun 2013-2016 terjadi peningkatan, yang dimana pada tahun 2013 produk domestik regional bruto sebanyak $6,30 \%$ dan ditahun 2016 sebanyak 9,06 \% itu dikarenakan sejalan dengan pertumbuhan penduduk dan semakin besarnya volume kegiatan pembangunan dari berbagai sektor, sehingga semakin bertambahnya wilayah permukiman di perkotaan.

${ }^{1}$ Andi Irawan dan Bayu Airlangga Putra, Kewirausahaan UKM: Pemikiran dan Pengalaman Ed. I (Cet.l; Yogyakarta: Graha Ilmu, 2007), h. 8.

${ }^{2}$ Andi Irawan dan Bayu Airlangga Putra, Kewirausahaan UKM. 
Sebagaimana diketahui bahwa kota atau daerah perkotaan mempunyai fungsi dan peranan yang sangat penting dan dominan dalam kehidupan masyarakat. ${ }^{3}$

Pertumbuhan ekonomi tersebut didorong oleh beberapa sektor, diantaranya yaitu industri rumahan (home industry) dan usaha kecil menengah (UKM). Perkembangan UKM oleh masyarakat dapat dimulai dari membentuk suatu perusahaan kecil (home industry) yang sebagian usaha dikembangkan berawal dari rumah sebagai pilihan tempat mereka bekerja, yang disebut dengan home based enterprises (usaha berbasis rumah). Dalam hal ini rumah tidak hanya dianggap sebagai salah satu kebutuhan dasar mereka tetapi juga dijadikan sesuatu yang produktif yaitu tempat aktivitas yang menghasilkan pendapatan dengan menjadi pengusaha kecil. ${ }^{4}$

Pengembangan industri rumahan (home industry) dan usaha mikro kecil menengah memiliki banyak dampak terhadap perekonomian. Salah satunya yaitu dalam menyerap tenaga kerja dan mengurangi kemiskinan.

Pada tahun 2015 jumlah tenaga kerja UKM mencapai lebih dari 132,3 juta orang mengalami peningkatan rata-rata sebesar 5,9\% dalam periode 2011-2015. Selain itu UKM juga memberikan dampak pada ekspor dan Investasi. Ekspor UKM non migas pada tahun 2015 mencapai 192,5 triliun dan nilai investasi yang terus mengalami peningkatan rata-rata sebesar 10,6\% dalam periode 2011-2015.

Mengenai masalah kemiskinan, hal ini terkait dengan masalah tingginya tingkat pengangguran yaitu sebesar 20\% (BPS 2015) yang akan berpengaruh terhadap keadaan aktivitas ekonomi maupun masalah sosial Kota Watampone ke depan, seperti masalah peningkatan kesejahteraan penduduk, yaitu tercatat bahwa terdapat 10,88

${ }^{3}$ BPS singkat dari Badan Pusat Statistik, yaitu suatu lembaga untuk mendapatkan data pertumbuhan ekonomi di Kota Watampone. Diakses melalui situs www.bonekab.bps.go.id.

${ }^{4}$ Akhiatul Akbar, "Konstribusi Usaha Mikro Kecil Menengah Berbasis Rumah Terhadap Pembangunan Ekonomi Kota Semarang" (Skripsi, Program Sarjana Ilmu Teknik Universitas Diponegoro, Semarang, 2009), h. 1. 
presentase rumah tangga miskin yang tersebar di seluruh kecamatan di Kota Watampone (BPS, 2014). Terkait dengan masalah tersebut, industri rumahan (home industry) dan usaha mikro kecil menengah diharapkan untuk dapat berkembang dengan baik, sehingga dapat berdampak nyata bagi perekonomian Kota Watampone dan masalah sosial seperti pengangguran dan kemiskinan dapat berkurang secara nyata. ${ }^{5}$

Mengenai industri rumahan atau home industry merupakan suatu peluang usaha yang mulai bermunculan dalam era sekarang karena semakin sempitnya lapangan kerja yang tersedia. Industri semacam ini dapat dikelola di dalam rumah sehingga dapat dipantau setiap saat. Usaha kecil semacam ini dikelola oleh orang-orang yang memiliki hubungan kekerabatan. Modal yang dibutuhkan usaha ini sedikit dan alat-alat yang digunakan bersifat manual.

Industri rumahan (home industry) juga termasuk ekonomi kreatif, sesuai dengan defenisi ekonomi kreatif itu sendiri merupakan konsep ekonomi baru yang memadukan informasi dan kreativitas yang mengandalkan ide, gagasan dan pengetahuan dari sumber daya manusia sebagai faktor produksi. ${ }^{6}$

Ekonomi kreatif yang didalamnya terdapat industri-industri kreatif memiliki daya tawar yang tinggi di dalam ekonomi yang berkelanjutan karena individunya memiliki modal kreativitas (creative capital) yang mereka pergunakan untuk menciptakan inovasi-inovasi. ${ }^{7}$

Pada penelitian ini akan memfokuskan pada industri rumahan (home industry) yang ada di Kota Watampone. Begitu banyak home industry yang ada di kota

${ }^{5}$ BPS singkat dari Badan Pusat Statistik, yaitu suatu lembaga untuk mendapatkan data pertumbuhan ekonomi di Kota Watampone. Diakses melalui situs www.bonekab.bps.go.id.

${ }^{6}$ Gusti Bagus Arjana, Geografi Pariwisata dan Ekonomi Kreatif, Ed. I (Cet. II; Jakarta: Rajawali Pers, 2016), h. 227.

${ }^{7}$ Mauled Moelyono, Menggerakkan Ekonomi Kreatif Antara Tuntunan dan Kebutuhan (Cet. I; Jakarta: Rajawali Pers, 2010), h. 237-240.

Jurnal Ilmiah Al Tsarwah 
Watampone, terkhusus industri rumahan yang berada dibawah naungan Dinas Koperasi dan UKM Kab. Bone dan industri rumahan yang tercatat pada Dinas Perindustrian Kab. Bone. Berdasarkan pemaparan tersebut, penelitian ini menjadi bahan menarik bagi penulis untuk melihat apakah industri rumahan (home industry) berkontribusi signifikan dalam meningkatkan pertumbuhan ekonomi di kota Watampone dan berapa persentase kontribusi industri rumahan dalam meningkatkan pertumbuhan ekonomi di kota Watampone. Berdasarkan uraian latar belakang diatas, maka penulis dapat menarik rumusan masalah yang akan menjadi bahan penelitian, yaitu: Apakah industri rumahan berkontribusi signifikan dalam meningkatkan pertumbuhan ekonomi di Kota Watampone dan Berapa jumlah persentase kontribusi industri rumahan dalam meningkatkan pertumbuhan ekonomi di Kota Watampone.

\section{METODE}

Dalam setiap karya tulis ilmiah pada prinsipnya selalu ditopang beberapa metode, baik dalam pengumpulan data maupun dalam pengolahannya seperti halnya dalam penulisan penelitian ini, penulis mempergunakan beberapa metode, yaitu:

\section{a. Jenis Penelitian}

Dilihat dari aspek tempat penelitian, maka jenis penelitian ini adalah penelitian lapangan (Field research). Field research ialah penelitian yang dilakukan dengan jalan mendatangi lokasi atau tempat penelitian. ${ }^{8}$ Penelitian ini merupakan penelitian lapangan dikarenakan peneliti datang langsung di Dinas Koperasi dan UKM Kab. Bone dan Dinas Perindustrian Kab. Bone serta industri rumahan dibawah naungan Dinas Koperasi dan UKM Kab. Bone untuk melakukan observasi dan melakukan pengamatan secara langsung.

\section{b. Pendekaatan penelitian}

${ }^{8}$ Sofar Silaen dan Widiyono, Metodologi Penelitian Sosial untuk Penulisan Skripsi dan Tesis ([t.c]; Jakarta: In Media, 2013), h. 17. 
Berdasarkan pada penenlitian ini yang berjudul "Kontribusi Industri Rumahan dalam Meningkatkan Pertumbuhan Ekonomi di Kota Watampone" menggunakan pendekatan penelitian kuantitatif. Pendekatan kuantitatif digunakan untuk menguji suatu teori, untuk menunjukan hubungan antarvariabel, dan ada pula yang bersifat mengembangkan konsep, mengembangkan pemahaman serta dalam ilmu-ilmu alam maupun ilmu-ilmu sosial. ${ }^{9}$ Alat yang digunakan untuk menyelesaikan masalah dengan bantuan aplikasi SPSS.

\section{c. Lokasi, Populasi dan Sampel Penelitian}

a. Lokasi

Adapun lokasi yang menjadi tempat penelitian yaitu Dinas Koperasi dan UKM Kab. Bone, lebih tepatnya bidang pemberdayaan usaha mikro kecil menengah dan beberapa pelaku industri rumahan yang berada dibawah naungan Dinas Koperasi dan UKM Kab. Bone serta Dinas Perindustrian Kab. Bone.

\section{b. Populasi}

Populasi adalah wilayah generalisasi yang terdiri atas: obyek/subyek yang mempunyai kualitas dan karakteristik tertentu yang ditetapkan oleh peneliti untuk dipelajari dan kemudian ditarik kesimpulannya. ${ }^{10}$ Populasi merujuk pada sekimpulan orang atau objek yang memiliki kesamaan dalam satu atau beberapa hal yang membentuk masalah pokok dalam suatu penelitian. ${ }^{11}$ Populasi meliputi obyek dan benda-benda alam lain. Populasi juga bukan sekedar jumlah yang ada pada obyek/subjek yang dipelajari, tetapi meliputi keseluruhan karakteristik/subyek yang dimiliki oleh subyek/obyyek itu. ${ }^{12}$ Berdasarkan uraian diatas dapat ditarik kesimpulan bahwa populasi pada penelitian ini adalah 66 industri rumahan (home industry) yang terbagi dari industri rumahan yang berada dibawah naungan Dinas Koperasi dan UKM Kab. Bone dan industri rumahan yang tercatat pada Dinas Perindustrian Kab. Bone.

\footnotetext{
${ }^{9}$ Bambang Prasetyo dan Lina Miftahul Jannah, Metode Penelitian Kuantitatif: Teori dan Aplikasi ([t.c]; Jakarta: RajaGrafindoPersada, 2005), h. 24.

${ }^{10}$ Sugiyono, Statiska untuk Penelitian, (Cet. 18; Bandung: Cv. Alfabeta. 2011), h. 61.

${ }^{11}$ Muhammad, Metodologi Penelitian Ekonomi Islam: Pendekatan Kuantitatif, (Cet. I; Jakarta: Rajawali Pers, 2008). h. 161

${ }^{12}$ Sugiyono, Metode Penelitian Kuantitatif, Kualitatif dan R\&D (Cet.21; Bandung: Alfabeta, 2014), h. 119. 


\section{c. Sampel}

Sampel adalah bagian dari jumlah dan karakteristik yang dimiliki oleh populasi tersebut. Untuk itu sampel yang diambil dari populasi harus betul-betul representatif (mewakili). ${ }^{13}$ Metode pengambilan sampel yang digunakan yaitu metode simple random sampling. Menurut sugiyono simple random sampling adalah pengambilan sampel penelitian yang dilakukan dengan menggunakan cara yang acak sederhana tanpa memperhartikan strata yang ada dalam populasi itu. Sampel akan diambil dari pelaku usaha home industry dibawah naungan Dinas Koperasi an UKM Kab. Bone dan Dinas Perindustrian Kab. Bone.

1) Untuk mengetahui industri rumahan berkontribusi signifikan dalam meningkatkan pertumbuhan ekonomi di Kota Watampone maka digunakan rumus slovin dalam pengambilan sampel, yaitu:

\section{Gambar . Rumus Slovin}

$$
\mathrm{n}=\frac{N}{N(d)^{2}+1}
$$

Keterangan:

$\mathrm{n}$ = Jumlah sampel yang dicari

$\mathrm{N}=$ Jumlah populasi

$d=$ Nilai presisi (ditentukan sebesar $90 \%$ atau $\alpha=0,1$ )

\section{Gambar 1.3}

\section{Hasil Penentuan Sampel Penelitian}

$$
\begin{aligned}
\mathrm{n} & =\frac{66}{66(0,1)^{2}+1} \\
& =\frac{66}{1,66} \\
& =39,7=40=60 \%
\end{aligned}
$$

${ }^{13}$ Sugiyono, Metode Penelitian Kuantitatif, h. 120. 
Berdasarkan perhitungan diatas, maka jumlah sampel pada penelitian ini adalah 39,7 atau dibulatkan menjadi 40 responden dan jika dipersentasikan sebesar $60 \%$ dari populasi.

2) Untuk mengetahui jumlah persentase kontribusi industri rumahan dalam meningkatkan pertumbuhan di Kota Watampone, maka peneliti mengambil satu sampel mewakili 40 industri rumahan, yaitu industri . makanan (Usaha Kue dan Roti Ainun Jaya) yang terletak di Jl. Mh. Thamrin.

\section{d. Data dan Sumber Data}

Adapun sumber data yang digunakan pada penelitian ini yaitu berasal dari data primer dan data sekunder.

\section{a. Data Primer}

Data primer adalah data yang langsung diperoleh dari sumber pertama di lokasi penelitian atau objek penelitian. ${ }^{14}$ Data primer dapat dikumpulkan melalui observasi dan wawancara sehingga pengumpulan data primer merupakan bagian integral dari proses penelitan ekonomi yang digunakan untuk pengambilan keputusan. ${ }^{15}$

Pengumpulan data primer dalam penelitian ini yaitu peneliti membagikan instrumen pertanyaan dan pernyataan kuesioner/angket kepada 40 responden pemilik industri rumahan untuk mengetahui industri rumahan berkontribusi signifikan dalam meningkatkan pertumubahan ekonomi di Kota Watampone, dan melakukan wawancara untuk memperoleh data pendapatan pada tahun 2013, 2014, 2015, dan 2016, dengan pemilik industri makanan (usaha kue dan roti Ainun Jaya) untuk mengetahui jumah persentase industri rumahan dalam meningkatkan pertumbuhan ekonomi di Kota Watampone.

b. Data Sekunder

Data sekunder adalah sumber data yang diperoleh penulis untuk mendukung data primer, dan sumber data yang digali melalui hasil pengolahan pihak kedua dari

${ }^{14}$ Burhan Bungin, Metodologi Penelitian Kuantitatif: Komunikasi, Ekonomi, dan Kebijakan Pubik Serta IImu-ilmu Sosial Lainnya, (Cet. 8; Jakarta: Prenadamedia Group, 2014), h.132.

${ }^{15}$ Muhammad, Metodologi Penelitian Ekonomi Islam: Pendekatan Kuantitatif, h. 103. 
hasil penelitian lapangan.. ${ }^{16}$ Pengumpulan data sekunder pada penelitian ini diperoleh dari data-data seperti dokumen, catatan-catatan, arsip, literature, daftar nama industri rumahan dan sumber lainnya yang terdapat pada Dinas Koperasi dan UKM Kab. Bone dan pelaku home industri serta Dinas Perindustrian Kab. Bone.

\section{a. Instrumen Penelitian}

Dalam mengumpulkan data untuk penelitian ini, instrumen yang digunakan sebagai berikut:

a. Observasi

Observasi adalah pengamatan yang dilakukan oleh seorang peneliti baik secara langsung maupun secara tidak langsung terhadap suatu objek yang diteliti dengan menggunakan instrument yang berupa pedoman penelitian dalam bentuk lembaran pengamatan atau lainnya. ${ }^{17}$ Observasi ini digunakan untuk melakukan pengamatan terhadap suatu penelitian yang dilakukan terhadap pelaku industri rumahan yang berada dibawah naungan Dinas Koperasi dan UKM Kab. Bone dan industri rumahan yang tercatat pada Dinas Perindustrian Kab. Bone.

b. Kuesioner

Kuesioner merupakan teknik pengumpulan data dengan cara memberikan atau menyebarkan seperangkat daftar pertanyaan atau pernyataan tertulis kepada responden untuk dijawab. ${ }^{18}$ Kuisioner dalam penelitian ini digunakan untuk mengumpulkan data, sebagai sumber data utama yang terdiri dari serangkaian pernyataan yang menggunakan skala likert. Menurut Kinner skala likert ini berhubungan dengan pernyataan tentang sikap responden terhadap sesuatu, misalnya sangat setuju/SS (5), setuju/S (4), kurang setuju /KS (3), tidak setuju/TS (2), sangat tidak setuju/STS (1). ${ }^{19}$

${ }^{16}$ Uma Sekeren, Research Methods For Business: Metodologi Penelitian untuk Bisnis, (Jakarta: Salemba Empat, 2006), h. 115.

${ }_{17}$ Muhammad, Metode Peneltian Ekonomi Islam : Pendekatan Kuantitatif, h. 150.

${ }^{18}$ Sugiyono, Metode Penelitian Bisnis (Cet. 10, Bandung: CV. Alfabeta, 2007), h. 135.

${ }^{19}$ Bungin Burhan, Metodologi Penelitian Sosial \& Ekonomi, h. 152-154. 
c. Dokumentasi

Dokumentasi merupakan pengumpulan data berupa data-data tertulis yang mengandung keterangan dan penjelasan serta pemikiran tentang fenomena yang masih akurat dan sesuai dengan masalah penelitian. Dokumentasi ini digunakan untuk mengumpulkan data sekunder yang terkait dengan data sumber dokumentasi dalam penelitian ini seperti artikel jurnal, buku-buku yang terkait dengan penelitian, surat kabar, majalah, artikel internet dan sumber lainnya.

\section{b. Teknik Pengumpulan Data}

Selanjutnya, jika dilihat dari segi tekhnik pengumpulan data, maka tekhnik pengumpulan data dapat dilakukan dengan kuesioner (angket), observasi (pengamatan) dan dokumentasi. ${ }^{20}$ Sedangkan metode atau yang digunakan dalam mengumpulkan data-data tersebut, yaitu sebagai berikut :

a. Kuesioner

Kuesioner (angket) merupakan teknik pengumpulan data dengan cara memberikan atau menyebarkan seperangkat daftar pernyataan atau pertanyaan tertulis kepada responden untuk dijawab. ${ }^{21}$ Instrument ini digunakan untuk mengumpulkan data penelitian yang berupa pertanyaan dan pernyataan yang diberikan kepada responden dengan skala likert. Skala likert disini diartikan sebagai skala yang dapat digunakan untuk mengukur sikap, pendapat, dan persepsi tentang fenomena sosial terhadap sesuatu. ${ }^{22}$ Adapun angket yang digunakan adalah angket tertutup dengan menyediakan dua jawaban yaitu ya dan tidak.

b. Wawancara

Pencarian data dengan teknik ini dilakukan dengan cara tanya jawab secara lisan dan bertatap muka langsung antara seorang atau beberapa orang pewawancara dengan seorang atau beberapa orang yang diwawancarai. ${ }^{23}$ Dalam penelitian ini, teknik ini digunakan untuk memperoleh data pendapatan pada tahun 2013, 2014, 2015, dan

\footnotetext{
${ }^{20}$ Sugiyono, Metode Penelitian Kuantitatif, h. 187.

${ }^{21}$ Sugiyono, Metode Penelitian Bisnis (Cet. 10, Bandung: CV. Alfabeta, 2007), h. 135.

22 Sugiyono, Metode Penelitian Bisnis, h. 86-87.

${ }^{23}$ Muhamad, Metodologi Penelitian Ekonomi Islam: h. 151.
} 
2016 dengan pemilik industri makanan (usaha kue dan roti Ainun Jaya) untuk mengetahui jumah persentase industri rumahan dalam meningkatkan pertumbuhan ekonomi di Kota Watampone.

c. Teknik observasi

Teknik observasi merupakan salah satu teknik pengumpulan data yang digunakan peneliti untuk mengadakan pengamatan dan pencatatan secara sistematis terhadap objek yang di teliti. Baik dalam situasi buatan yang secara khusus diadakan atau laboratorium maupun dalam situasi alamiah atau sebenarnya (lapangan). ${ }^{24}$ Observasi adalah pengamatan yang dilakukan oleh seorang peneliti baik secara lansung maupun tidak langsung terhadap suatu objek yang diteliti dengan menggunakan instrument yang berupa pedoman penelitian dalam bentuk lembaran pengamatan atau lainnya. Dalam penelitian ini peneliti melakukan observasi pada Dinas Koperasi dan UKM Kab. Bone serta pelaku home industri yang berada dibawa naungan Dinas Koperasi dan UKM Kab. Bone dan industri rumahan yang tercatat pada Dinas Perindustrian Kab. Bone.

d. Dokumentasi

Dokumentasi yaitu mencari data mengenai hal-hal yang berupa catatan, buku, surat kabar, majalah, notulen, surat kabar dan sebagainya. ${ }^{25}$ Metode dokumentasi dalam penelitian ini akan mencoba mencari dokumen-dokumen yang terkait dengan industri rumahan dalam kaitannya pada pertumbuhan ekonomi. Selain itu, metode ini digunakan untuk mengabadikan proses dalam penelitian ini.

\section{c. Teknik Analisis Data}

24 Maman Abdurrahman dan Sambas Ali Muhidin, Panduan Praktis Memahami Penelitian, (Cet. 1; Bandung: CV. Pustaka Setia, 2011), h. 85.

${ }^{25}$ Sukandar Rumidi, Metodologi Penelitian (Petunjuk Praktis Untuk Peneliti Pemula), (Yogyakarta: Gadjah Mada University Press, 2012), h. 101. 
Dalam penelitian kuantitatif, analisis data merupakan kegiatan setelah data dari seluruh responden atau sumber data lain terkumpul. ${ }^{26}$ Analisis data merupakan suatu cara untuk menganalisa data yang diperoleh dengan tujuan untuk menguji rumusan masalah. Peneliti harus memastikan pola analisis mana yang akan digunakan tergantung pada jenis data yang dikumpulkan. Untuk menganalisis data peneliti menggunakan metode pengukuran data dan teknik pengolahan data. Adapun tehnik analisis data yang digunakan dalam penelitian ini antara lain:

1) Untuk mengetahui industri rumahan berkontribusi signifikan dalam meningkatkan pertumbuhan ekonomi di Kota Watampone, maka menggunakan teknik analisis data sebagai berikut:

a. Diskripsi Persentase

Alat analisis ini akan digunakan untuk mendeskripsikan atau memberikan gambaran terhadap karakteristik responden yang dijadikan sebagai sampel dalam penelitian ini agar lebih mudah dalam memahaminya sebagaimana adanya tanpa membuat kesimpulan yang berlaku secara umum. ${ }^{27}$

Langkah-langkah yang ditempuh dalam menggunakan alat analisis ini:

1. Membuat tabel distribusi untuk data responden.

2. Menentukan jawaban responden dengan ketentuan yang telah ditetapkan.

3. Menjumlah jawaban yang diperoleh dari tiap-tiap responden.

4. Memasukkan skor jawaban tersebut ke dalam rumus, yaitu:

\section{Gambar 1.4}

\section{Rumus Diskripsi Presentase}

$$
\%=\frac{n}{N} \mathrm{X} 100 \%
$$

${ }^{26}$ Sugiyoo, Metodologi Penelitian Pendidikan : Pendektan kuantitafif, kualitatif dan R\&D, (Cet.22: Bandung; Alfabeta, 2015), h. 207.

${ }^{27}$ Husein Umar, Research Methods in Finance and Banking (Cet.2; Jakarta:PT. Gramedia Pustaka Umum.2007), h. 122. 
Keterangan:

$$
\begin{aligned}
\% & =\text { Persentase } \\
n & =\text { Jumlah skor yang diperoleh dari data } \\
\mathrm{N} & =\text { Jumlah skor maksimal }
\end{aligned}
$$

b. Uji Validitas dan Uji Reliabilitas

Setelah melakukan pengumpulan data dengan menggunakan kuisioner yang telah disebar oleh peneliti kepada responden selanjutnya hasil dari pengumpulan data tersebut akan diproses dengan menggunakan uji validitas dan reabilitas.

Dengan demikian, validitas dan reliabilitas merupakan syarat bagi angket penelitian yang baik. Validitas menunjukkan kinerja angket dalam mengukur apa yang diukur, sedangkan reliabilitas menunjukkan bahwa angket tersebut konsisten apabila digunakan untuk mengukur gejala yang sama. Tujuan pengujian validitas dan reliabilitas angket adalah untuk meyakinkan bahwa angket yang disusun benar-benar baik dalam mengukur gejala dan menghasilkan data yang valid. ${ }^{28}$

Validitas adalah suatu ukuran yang menunjukkan tingkat-tingkat kevalitan dan kesahan suatu instrument. Ketentuan validitas instrumen dianggap valid apabila dapat mengungkapkan data variabel yang diteliti secara tepat. ${ }^{29}$ Dalam pengujian instrument pengumpulan data, validitas bisa dibedakan menjadi validitas faktor dan validitas item. Validitas faktor diukur bila item yang disusun menggunakan lebih dari satu faktor (antara faktor satu dengan yang lain ada kesamaan). Pengukuran validitas faktor inilah dengan cara mengorelasikan antara skor faktor (penjumlahan item dalam satu faktor) dengan skor total faktor (total keseluruahan faktor), sedangkan pengukuran validitas item dengan cara mengorelasikan antara skor item dengan skor total item. ${ }^{30}$

${ }^{28}$ Sugiyono, Statistika Untuk Penelitian, h. 348.

${ }^{29}$ Suharsimi Arikunto, Prosedur Penelitian Suatu Pendekatan Praktek, Edisi Revisi V, (Cet. XII; Jakarta: PT. Rineka Cipta, 2002), h. 107.

${ }^{30}$ Dwi Priyatno, Mandiri Belajar SPSS (Statistical Product and Service Solution) : Untuk Analisis Data dan Uji Statistik, h. 16. 
Analisis ini dengan cara mengorelasikan masing-masing skor-item dengan skor total. Skor total adalah penjumlahan dari keseluruhan item. Item-item pertanyaan yang berkorelasi signifikan dengan skor total menujukkan item-item tersebut mampu memberikan dukungan dalam mengungkapkan apa yang ingin diungkapkan. Kofisien korelasi item-total dengan Korelasi Product Moment Pearson dapat dicari dengan menggunakan rumus sebagai berikut :

\section{Gambar. Rumus Korelasi}

$$
r_{x y}=\frac{N \sum X Y-\left(\sum X\right)\left(\sum Y\right)}{\sqrt{\left[N \sum X^{2}-\left(\sum X\right)^{2}\right]\left[N \sum Y^{2}-\left(\sum Y\right)^{2}\right]}}
$$

Keterangan :

$r_{\mathrm{xy}}=$ Koefisien Korelasi Item-Total Korelasi Product Moment Pearson

$\mathrm{X}=$ Skor Butir

$\mathrm{Y} \quad=$ Skor Total yang Diperoleh

$\mathrm{N}=$ Jumlah Responden

$\sum X^{2}=$ Jumlah Kuadrat Nilai $X$

$\sum Y^{2}=$ Jumlah Kuadrat Nilai $Y$

Penguji menggunakan uji dua sisi dengan taraf signifikansi 0,05 . Kriteria penguji adalah sebagai berikut :

1) Jika $r_{\text {nitung }} \geq r$ tabel (uji 2 dengan sig. 0,05) maka instrument atau item-item pertanyaan berkorelasi signifikan terhadap skor total (dinyatakan valid). 
2) Jika $r$ hitung $\leq r$ tabel (uji 2 dengan sig. 0,05) maka instrument atau item-item pertanyaan berkorelasi tidak signifikan terhadap skor total (dinyatakan tidak valid) ${ }^{31}$

Namun untuk lebih memudahkan dalam melakukan perhitungan korelasi tersebut, peneliti tidak melakukannya secara manual dengan menggunakan rumus diatas, akan tetapi menggunakan program SPSS di mana rumus tersebut diatas sudah terprogram di dalamnya sehingga peneliti dapat melakukan perhitungan dengan mudah, cepat dan tepat.

Reabilitas instrument adalah hasil pengukuran yang dapat dipercaya. Reliabilitas instrument diperlukan untuk mendapatkan sesuai dengan tujuan pengukuran. Untuk mencapai hal yang dilakukan uji reliabilitas dengan menggunakan metode Alpha Cronbach's diukur berdasarkan Alpha Cronbach's 0 sampai 1. Variabel dikatakan reliabel jika memberikan nilai Cronbach Alpha $>0,60 .{ }^{32}$

Teknik uji reabilitas yang digunakan dalam penelitian ini, adalah Alpha Cronbach. Rumusnya yang sering digunakan adalah seperti dibawah ini:

\section{Gambar. Rumus Reabilitas}

$$
\alpha=\left[\frac{k}{k-1}\right]\left[1-\frac{\sum \sigma_{b}^{2}}{\sigma_{b}^{2}}\right]
$$

Keterangan :

$$
\begin{array}{ll}
\alpha & =\text { Reliabilitas Instrumen } \\
\boldsymbol{k} & =\text { Banyaknya Butir Pertanyaan } \\
\sum \sigma_{b}^{2} & =\text { Jumlah Varian Butir }
\end{array}
$$

${ }^{31}$ Dwi Priyatno, Mandiri Belajar SPSS (Statistical Product and Service Solution) : Untuk Analisis Data dan Uji Statistik, h. 18.

${ }^{32}$ Suharsimi Arikunto, Prosedur Penelitian Suatu Pendekatan Praktek, h. 144-145. 


$$
\sigma_{b}^{2} \quad=\text { Varian Total }{ }^{33}
$$

Atau bisa juga menggunakan bantuan dari program SPSS di mana rumus tersebut diatas sudah terprogram di dalamnya, sehingga hanya tinggal memasukkan data, kemudian diproses dan melihat nilai Cronbach's Alpha-nya pada Reliability Statistics.

\section{c. Uji Persyaratan Regresi}

Di dalam analisis regresi terdapat beberapa uji persyaratan yang harus dilalui agar analisis tersebut dapat terlihat lebih dari biasanya. Uji persyaratan tersebut yaitu:

1. Uji normalitas yaitu suatu pengujian yang dilakukan dengan tujuan untuk mengetahui apakah populasi data untuk semua variable dalam penelitian ini mengikuti pola distribusi normal ataukah tidak. Pengujian normalitas dilakukan dengan tehik kolmogrov-Smimov dengan kriteria jika nilai signifikansinya $>0,05$ maka data berdistribusi normal begitupula sebaliknya.

2. Uji Linearitas dimaksudkan untuk mengetahui apakah dua variable mempunyai hubungan yang berbentuk linear atau tidak secara signifikan. Untuk memastikan bersifat linear atau tidak, dapat dilakukan dengan dua cara yaitu : (1) dengan melihat nilai signifikansi linearity-nya, apabila $>$ 0,05 maka terdapat hubungan linear secara signifikan antara variable independen dengan variable dependennya, begitupun sebaliknya; (2) dengan melihat nilai $\mathrm{F}$ hitung dan $\mathrm{F}$ tabel, apabila $\mathrm{F}$ hitung $<\mathrm{F}$ tabel, maka terdapat hubungan linear secara signifikan antara variable independen dengan variable dependen, begitupun sebaliknya. ${ }^{34}$

d. Uji Regresi Sederhana.

Analisis regresi lebih akurat dalam melakukan analisis korelasi. Dengan analisis regresi peramalan atau perkiraan nilai variabel terikat pada nilai variabel bebas lebih akurat. ${ }^{35}$ Regresi sederhana digunakan untuk menganalisis hubungan antara variable

${ }^{33}$ Dwi Priyatno, Mandiri Belajar SPSS (Statistical Product and Service Solution) : Untuk Analisis Data dan Uji Statistik, h. 25.

${ }^{34}$ Dwi Priyanto, Mandiri Belajar SPSS: untuk analisis Data dan Uji Statistik, h. 28-39.

${ }^{35}$ Iqbal Hasan, Pokok-Pokok Materi Statistik 1, (Cet. 1;Jakarta: Bumi Aksara, 2002), h. 250. 
bebas dengan variable terikat. Model yang digunakan untuk melakukan analisis regresi linier sederhana adalah sebagai berikut:

Gambar. Rumus Regresi Sederhana

$$
\mathbf{Y}=\mathbf{a}+\mathbf{b X}
$$

Keterangan:

$\mathbf{Y}=$ variable terikat

$\mathbf{a}=$ intersep

$\mathbf{b}=$ koefisien regresi/slop

$\mathbf{X}=$ variable bebas

e. Uji Hipotesis

Hipotesis berasal dari dua kata hypo (belum tentu benar) dan tesis (kesimpulan). ${ }^{36}$ Hipotesis adalah pendapat, jawaban, atau dugaan yang bersifat sementara dari suatu persoalan yang diajukan, yang kebenarannya masih perlu dibuktikan lebih lanjut. ${ }^{37}$

1) Untuk mengetahui hipotesis pada penelitian ini yaitu menggunakan uji t-test. Untuk mengetahui keterandalan serta kemaknaan nilai koefisien regresi, sehingga dapat diketahui apakah variabel industri rumahan $(\mathrm{X})$ terhadap pertumbuhan ekonomi $(\mathrm{Y})$ signifikan atau tidak. Kriteria pengujian yang digunakan yaitu:

a) Ho diterima jika $t$ hitung $<t_{\text {tabel }}$ (tidak ada pengaruh yang signifikan antara industri rumahan terhadap peningkatan pertumbuhan ekonomi).

b) Ho ditolak jika $t$ hitung $>t_{\text {tabel }}$ (ada pengaruh yang signifikan antara industri rumahan terhadap peningkatan pertumbuhan ekonomi.

${ }^{36} J u l i a n s y a h$ Noor, Metodologi Penelitian: Skripsi, Tesis, Disertasi, dan Karya Ilmiah (Cet. 4; Jakarta: Prenadamedia Group, 2014), h. 79.

${ }^{37}$ Teguh Muhammad, Metodologi Penelitian Ekonomi Teori dan Aplikasi (Cet. II; Jakarta: PT Rajagrafindo Persada, 2005), h. 58. 
2) Untuk mengetahui jumlah persentase kontribusi industri rumahan dalam meningkatkan pertumbuhan ekonomi di Kota Watampone, maka digunakan rumus sebagai berikut:

\section{Gambar. Rumus Persentase Pendapatan Industri Rumahan}

$$
\mathrm{Y}=\frac{Y 2-Y 1}{Y 2} \times 100 \%
$$

Dimana:

$\mathrm{Y}=$ Pendapatan

$\mathrm{Y}_{2}=$ Pendapatan Tahun Sekarang

$\mathrm{Y}_{1}=$ Pendapatan Tahun Sebelum

Sedangkan perhitungan pertumbuhan ekonomi dapat dihitung dengan nilai PDB, yaitu PDB berdasarkan harga konstan. Adapun rumus untuk menhitung pertumbuhan ekonomi yaitu sebagai berikut:

\section{Gambar. Rumus Pertumbuhan Ekonomi}

$$
\mathrm{Gt}=\frac{(P D B t-P D B t-1)}{P D B t-t} \times 100 \%
$$

Keterangan:

$\mathrm{Gt}=$ Pertumbuhan ekonomi periode $\mathrm{t}$ (triwulan atau tahunan)

$\mathrm{PDB}(\mathrm{t})=$ Produk domestik bruto periode $\mathrm{t}$ (berdasarkan harga konstan)

PDB $(\mathrm{t}-1)=$ Produk domestik bruto periode sebelumnya .

\section{Hasil dan Pembahasan}

\section{Persentase Kontribusi Industri Rumahan dalam Meningkatkan Pertumbuhan Ekonomi}

Untuk mengetahui persentase kontribusi industri rumahan dalam meningkatkan pertumbuhan ekonomi, maka akan di deskripsikan data pendapatan industri rumahan 
dalam hal ini industri makanan (usaha kue dan roti Ainun Jaya) dan data pertumbahan ekonomi Kabupaten Bone yang diuraikan sebagai berikut:

\section{Tabel. Persentase Industri Rumahan dan Pertumbuhan Ekonomi Kab. Bone Tahun 2013-2016}

\begin{tabular}{|c|c|c|}
\hline Tahun & $\begin{array}{c}\text { Pendapatan Industri Rumahan } \\
\text { Usaha Kue dan Roti Ainun } \\
\text { Jaya (\%) }\end{array}$ & $\begin{array}{c}\text { Pertumbuhan } \\
\text { Ekonomi (\%) }\end{array}$ \\
\hline 2013 & - & - \\
\hline 2014 & 4,76 & 33 \\
\hline 2015 & $-16,66$ & $-14,95$ \\
\hline 2016 & 10 & 8,49 \\
\hline
\end{tabular}

Sumber: Data Primer dan Sekunder, diolah 2018

Berdasarkan tabel diatas, menjelaskan bahwa pada tahun 2014 persentase kontribusi industri rumahan usaha kue dan roti Ainun Jaya yaitu sebesar 4,76\% dan pertumbuhan ekonomi sebesar 33\%. Pada tahun 2015 industri rumahan usaha kue dan roti Ainun Jaya turun menjadi $-16,66 \%$ dan pertumbuhan ekonomi juga mengalami penurunan menjadi $-14,95 \%$ dan pada tahun 2016 persentase industri rumahan naik menjadi $10 \%$ dan diikuti dengan kenaikan pertumbuhan ekonomi sebesar $8,49 \%$.

Untuk lebih jelasnya, maka dijelaskan dalam grafik sebagai berikut: 


\section{Grafik. Persentase Industri Rumahan dan Pertumbuhan Ekonomi Kab. Bone Tahun 2013-2016}

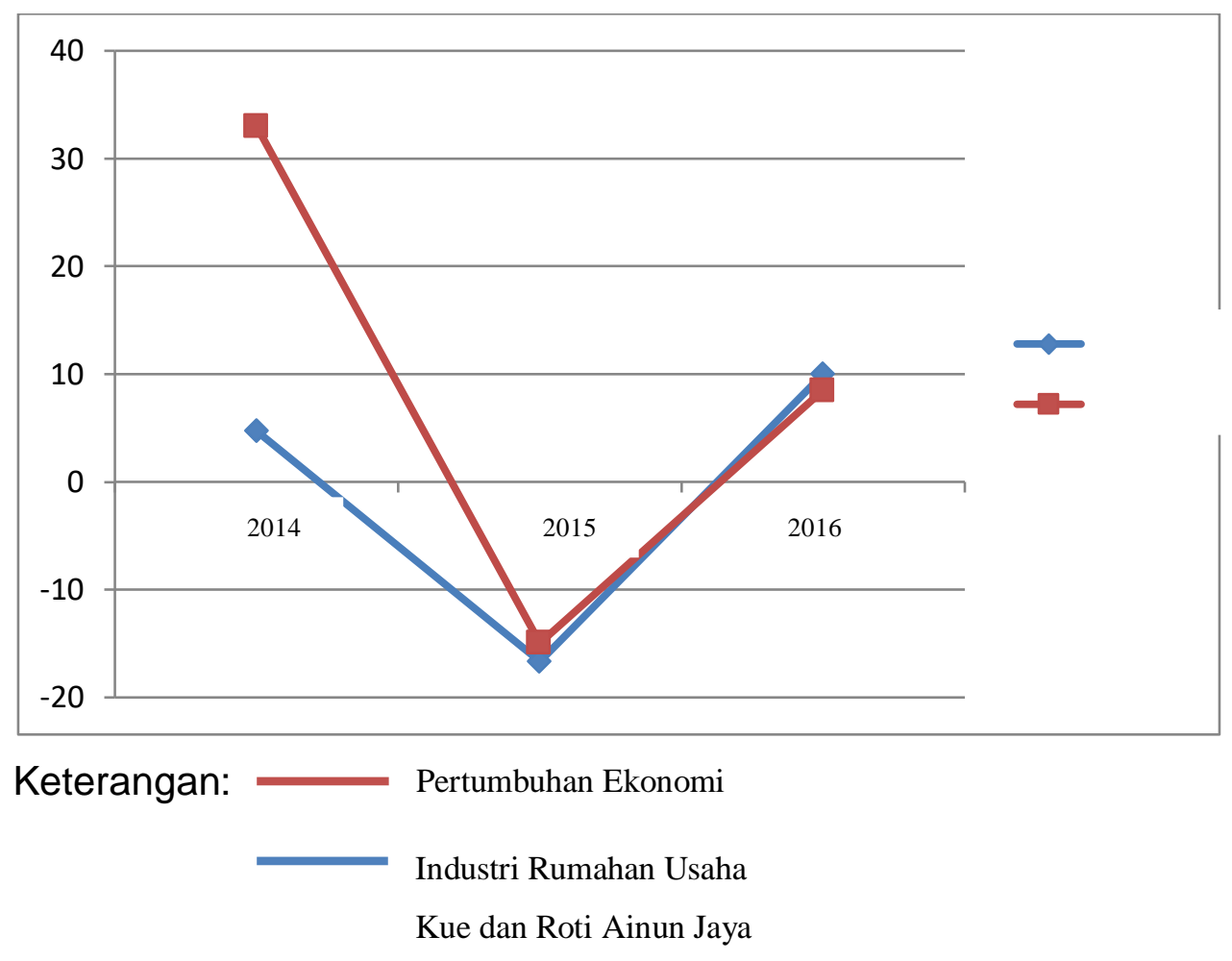

Berdasarkan grafik diatas, menjelaskan bahwa pada tahun 2014 persentase kontribusi industri rumahan usaha kue dan roti Ainun Jaya yaitu sebesar 4,76\% dan pertumbuhan ekonomi sebesar 33\%. Pada tahun 2015 industri rumahan usaha kue dan roti Ainun Jaya turun menjadi $-16,66 \%$ dan pertumbuhan ekonomi juga mengalami penurunan menjadi $-14,95 \%$ dan pada tahun 2016 persentase industri rumahan naik menjadi $10 \%$ dan diikuti dengan kenaikan pertumbuhan ekonomi sebesar 8,49\%.

\section{Penetapan Hasil Hipotesis Untuk Rumusan Masalah Kedua}


Adapun penetapan rumusan masalah kedua yaitu:

1. Pada tahun 2014-2015 pendapatan industri rumahan usaha kue dan roti Ainun Jaya mengalami penurunan dari $4,76 \%$ menjadi $-16,66 \%$, penurunan pendapatan industri rumahan tersebut diikuti dengan penurunan pertumbuhan ekonomi pada tahun 2014 dan 2015 yaitu dari 33\% menjadi -14,95\%. Jadi industri rumahan usaha kue dan roti Ainun Jaya memberikan kontribusi positif terhadap pertumbuhan ekonomi Kab. Bone.

2. Pada tahun 2015-2016 pendapatan industri rumahan usaha kue dan roti Ainun Jaya mengalami kenaikan dari $-16,66 \%$ menjadi $10 \%$, kenaikan pendapatan industri rumahan pada tahun 2015-2016 diikuti dengan kenaikan pertumbuhan ekonomi pada tahun tersebut dimana pertumbuhan ekonomi pada tahun 2015 yaitu $-14,95 \%$ naik menjadi $8,49 \%$. Jadi industri rumahan usaha kue dan roti Ainun Jaya memberikan kontribusi positif terhadap pertumbuhan ekonomi Kab. Bone.

\section{Pembahasan Hasil Hipotesis}

Dari hasil yang diperoleh diatas dapat disimpulkan bahwa industri rumahan usaha kue dan roti Ainun Jaya memberikan kontribusi yang positif terhadap pertumbuhan ekonomi. Dimana jika pendapatan dari industri rumahan kue dan roti Ainun Jaya meningkat akan diikuti dengan peningkatan pertumbuhan ekonomi. Namun sebaliknya jika pendapatan industri rumahan kue dan roti Ainun Jaya mengalami penurunan maka pertumbuhan ekonomi juga mengalami penurunan. Hal ini menunjukkan bahwa industri rumahan memberikan kontribusi yang positif terhadap pertumbuhan ekonomi.

Apabila pendapatan dari sebuah industri rumahan mengalami kenaikan maka akan meningkatkan produksi dari industri rumahan tersebut, selain itu industri rumahan juga mengalami perkembangan apabila pendapatannya meningkat. Dengan meningkatnya pendapatan industri rumahan maka dapat meningkatkan kualitas industri rumahan seperti membuka cabang-cabang usaha baru di daerah lain sehingga dapat menambah lapangan pekerjaan. Dengan adanya lapangan pekerjaan yang baru maka 
tingkat pengangguran juga akan semakin berkurang. Hal ini dapat meningkatkan pertumbuhan ekonomi.

Selain itu, apabila pendapatan dari suatu industri rumahan meningkat maka produksi dari industri rumahan tersebut juga akan mengalami peningkatan. Apabila produksi dari suatu industri rumahan meningkat maka produknya dapat di distribusikan ke luar negeri, bukan hanya dalam negeri saja dengan begitu maka pertumbuhan ekonomi akan mengalami peningkatan.

Sebaliknya apabila industri rumahan tidak berjalan dengan baik maka akan berdampak negatif terhadap pertumbuhan ekonomi, dikarenakan pemerintah akan menanggung dampak tersebut seperti tingkat pengangguran semakin tinggi dan masalah lapangan pekerjaan. Hal ini tentunya akan berpengaruh terhadap pertumbuhan ekonomi.

\section{KESIMPULAN DAN SARAN}

\section{Kesimpulan}

Berdasarkan hasil penelitian pada penelitian ini dapat ditarik sebuah kesimpulan yaitu sebagai berikut:

1. Secara parsial hasil analisis regresi menunjukkan industri rumahan berkontribusi signifikan dalam meningkatkan pertumbuhan ekonomi di Kota Watampone, karena thitung $>\mathrm{t}$ tabel $(1,362>0,181)$ sehingga $\mathrm{H} 0$ ditolak dan $\mathrm{H} 1$ diterima.

2. Pada tahun 2014-2015 pendapatan industri rumahan usaha kue dan roti Ainun Jaya mengalami penurunan dari $4,76 \%$ menjadi $-16,66 \%$, penurunan pendapatan industri rumahan tersebut diikuti dengan penurunan pertumbuhan ekonomi pada tahun 2014 dan 2015 yaitu dari 33\% menjadi -14,95. Pada tahun 2015-2016 pendapatan industri rumahan usaha kue dan roti Ainun Jaya mengalami kenaikan dari $-16,66 \%$ menjadi $10 \%$, kenaikan pendapatan industri rumahan pada tahun 2015-2016 diikuti dengan kenaikan pertumbuhan ekonomi pada tahun tersebut dimana pertumbuhan ekonomi pada tahun 2015 yaitu - 
14,95\% naik menjadi 8,49\%. Jadi industri rumahan usaha kue dan roti Ainun Jaya memberikan kontribusi positif terhadap pertumbuhan ekonomi Kab. Bone karena \%pendapatan industri rumahan dan \%pertumbuhan ekonomi searah (=) sehingga memberikan kontribusi yang positif sehingga $\mathrm{HO}$ ditolak dan $\mathrm{H} 1$ diterima.

\section{Saran}

Berdasarkan hasil penelitian dan analisis data, maka penulis memberikan saran kepada pihak- pihak yang terkait, sebagai berikut :

1. Dengan adanya penelitian ini diharapkan masyarakat menambah wawasan dan lebih giat untuk menciptakan usaha walaupun berbasis industri rumahan (home industry), karena dengan terciptanya suatu usaha dapat membantu perekonomian, baik pribadi, keluarga, masyarakat maupun terhadap pertumbuhan ekonomi suatu daerah.

2. Dengan adanya penelitian ini diharapkan agar pemerintah Kabupaten Bone semakin memperhatikan industri rumahan yang ada di kota Watampone baik yang sudah memiliki suatu usaha maupun baru ingin memulai suatu usaha dengan meningkatkan pelatihan-pelatihan sehingga industri rumahan yang ada di kota Watampone semakin berkembang dengan baik. 


\section{DAFTAR PUSTAKA}

Abdurrahman, Maman dan Sambas Ali Muhidin. Panduan Praktis Memahami Penelitian, Cet. 1; Bandung: CV. Pustaka Setia, 2011.

Akbar, Akhiatul. "Konstribusi Usaha Mikro Kecil Menengah Berbasis Rumah Terhadap Pembangunan Ekonomi Kota Semarang", Skripsi, Program Sarjana IImu Teknik Universitas Diponegoro, Semarang, 2009.

Alma, Buchari. Kewirausahaan untuk Mahasiswa dan Umum, Cet.20; Bandung: Alfabeta, 2014.

Arikunto, Suharsimi. Prosedur Penelitian Suatu Pendekatan Praktek, Edisi Revisi V, Cet. XII; Jakarta: PT. Rineka Cipta, 2002.

Arjana, Gusti Bagus. Geografi Pariwisata dan Ekonomi Kreatif, Ed. I. Cet. II; Jakarta: Rajawali Pers, 2016.

Basar, Ade Muhammad Alimul. "Peranan Usaha Kecil Menengah Dalam Meningkatkan Kesejahteraan Masyarakat Di Kecamatan Cibeureum Kabupaten Kuningan", Skripsi. Jurusan Muamalah dan Ekonomi Perbankan Islam. Fakultas Syariah IAN Syekh Nurjati Cerebon, 2015.

BPS singkat dari Badan Pusat Statistik, yaitu suatu lembaga untuk mendapatkan data pertumbuhan ekonomi di Kota Watampone. Diakses melalui situs www.bonekab.bps.go.id.

Bungin, Burhan. Metodologi Penelitian Kuantitatif: Komunikasi, Ekonomi, dan Kebijakan Pubik Serta IImu-ilmu Sosial Lainnya, Cet. 8; Jakarta: Prenadamedia Group, 2014.

Dawabah, Asyraf Muhammad. Menjadi Pengusaha Muslim, Cet. 1; Jakarta: Pustaka AlKautsar, 2005.

Hakim, Abdul. Ekonomi Pembanguan, Ed. I. Cet.II; Yogyakarta: CV Adipura, 2004.

Hasan, Iqbal. Pokok-Pokok Materi Statistik 1, Cet. 1; Jakarta: Bumi Aksara, 2002.

Hasan. M. Iqbal, Pokok-pokok Metodelogi dan Aplikasinya, [t.c]; Jakarta: Ghalia Indonesia, 2002.

Hendro. Dasar-Dasar Kewirausahaan Panduan Bagi Mahasiswa Untuk Mengenal, Memahami, dan Memasuki Dunia Bisnis, [t.cet]; Jakarta: Penerbit Erlangga, 2011.

Irawan, Andi dan Bayu Airlangga Putra. Kewirausahaan UKM: Pemikiran dan Pengalaman Ed. I, Cet.I; Yogyakarta: Graha IImu, 2007.

Moelyono, Mauled. Menggerakkan Ekonomi Kreatif Antara Tuntunan dan Kebutuhan. Cet. I; Jakarta: Rajawali Pers, ${ }_{73}^{n}$ ).

Muawil, Sitti Rahma. "Kontribusi Ind Rumahan dalam Meningkatkan Pendapatan Rumah Tangga", Skripsi, Program Studi Ekonomi Islam, Jurusan Syariah. STAIN Watampone. Watampone, 2015. 
Muhammad, Teguh. Metodologi Penelitian Ekonomi Teori dan Aplikasi, Cet. II; Jakarta: PT Rajagrafindo Persada, 2005.

Muhammad. Metodologi Penelitian Ekonomi Islam: Pendekatan Kuantitatif, Cet. I; Jakarta: Rajawali Pers, 2008.

Noor, Juliansyah. Metodologi Penelitian: Skripsi, Tesis, Disertasi, dan Karya IImiah, Cet. 4; Jakarta: Prenadamedia Group, 2014.

Prasetyo, Bambang dan Lina Miftahul Jannah. Metode Penelitian Kuantitatif: Teori dan Aplikasi, [t.c]; Jakarta: RajaGrafindoPersada, 2005.

Priyatno. Dwi. Mandiri Belajar SPSS (Statistical Product and Service Solution): Untuk Analisis Data dan Uji Statistik, Cet. II ; Yogyakarta : MediaKom, 2008.

Raselawati, Ade, "Pengaruh Perkembangan Usaha Kecil Menengah Terhadap Pertumbuhan Ekonomi Pada Sektor UKM Di Indonesia" Skripsi, Program Sarjana Ekonomi Dan Bisnis Universitas Islam Negeri Syarif Hidayatullah Jakarta, 2011.

Rumidi, Sukandar. Metodologi Penelitian (Petunjuk Praktis Untuk Peneliti Pemula), Yogyakarta: Gadjah Mada University Press, 2012.

S, Nasution. Metodologi Research IImiah, [t.c]; Jakarta: Bumi Aksara , 2000.

Sekeren, Uma. Research Methods For Business: Metodologi Penelitian untuk Bisnis, Jakarta: Salemba Empat, 2006.

Silaen, Sofar dan Widiyono. Metodologi Penelitian Sosial untuk Penulisan Skripsi dan Tesis, [t.c]; Jakarta: In Media 2013.

Subandi, Sistem Ekonomi Indonesia, Cet. 7; Bandung: Alfabeta, 2012.

Sudaryono dkk. Kewirausahaan, Ed.1, [t.cet]; Yogyakarta: C.V Andi Offset, 2011.

Sugiyono. Metode Penelitian Bisnis, Cet. 10, Bandung: CV. Alfabeta, 2007.

Sugiyono. Metode Penelitian Kuantitatif, Kualitatif dan R\&D, Cet. 21; Bandung: Alfabeta, 2014.

Sugiyono. Metodologi Penelitian Pendidikan : Pendektan kuantitafif, kualitatif dan R\&D, Cet.22: Bandung; Alfabeta, 2015.

Sugiyono. Statiska untuk Penelitian, Cet. 18; Bandung: Cv. Alfabeta. 2011. 